\title{
Chemical composition and structural characterization of contrasting colors of soybean seed coats
}

\section{Composição química e caracterização estrutural de tegumentos de sementes de soja com cores contrastantes}

\author{
Carlos André Bahry ${ }^{1 *}$; Tanize dos Santos Acunha²; Juliana Aparecida Fernando \\ Fábio Clasen Chaves ${ }^{3}$; Maicon Nardino ${ }^{4}$; Paulo Dejalma Zimmer ${ }^{3}$
}

\begin{abstract}
Seed coats provide protection to seeds and present differential traits between soybean genotypes. The aim of this study was to determine the chemical composition and analyze the internal coat structure of soybean genotypes with contrasting seed coat color, as well as to evaluate the rate of water absorption by seeds. Four genotypes were tested: two genotypes with black seed coat (IAC and TP lines) and two genotypes with yellow seed coat (BMX Potência RR and CD 202 cultivars). The seeds of the four genotypes were grown during the 2012/0213 crop season, in a greenhouse at the Embrapa Clima Temperado - Estação Experimental Terras Baixas. After the harvest, the seeds were stored in controlled conditions for five months. After this period, concentration of phenolic compounds, antioxidant potential, anthocyanins, carotenoids, and lignin in seed coats were determined at the Universidade Federal de Pelotas. Internal coat structure was examined on anatomical slides and documented with image capturing software using a microscope at the Escola Superior de Agricultura Luiz de Queiroz, Universidade de São Paulo. Finally, water absorption of contrasting seeds was evaluated at 42 hours of imbibition. Experimental design was completely randomized with five replicates. Data were subjected to analysis of variance and the means were compared by Tukey's test, at $5 \%$ probability level. Coat structure was characterized by the image analysis. Imbibition data were subjected to regression analysis. The concentration of phenolic compounds, antioxidant potential, anthocyanins, carotenoids, and lignin are higher in black coated genotypes. Their palisade layer and hourglass cells are thicker and the former are more lignified in black seed coats compared to yellow seed coats. The water gain by the seeds is dependent on the conditions in which the seeds were formed and varied between genotypes, independent of coat coloration and lignin concentration.
\end{abstract}

Key words: Anthocyanins, internal structure, lignin, water absorption

\section{Resumo}

Os tegumentos desempenham importante função de proteção às sementes, e podem apresentar características diferenciais entre os genótipos de soja. O objetivo do trabalho foi determinar a composição química e analisar a estrutura interna dos tegumentos de genótipos de soja com cores contrastantes,

${ }^{1}$ Prof. Adjunto, Curso de Agronomia, Universidade Tecnológica Federal do Paraná, UTFPR, Pato Branco, PR, Brasil. E-mail: carlosbahry@utfpr.edu.br

2 Discente do Curso de Doctorado en Biologia y Ciências de la Alimentation de la Universidad Autonoma de Madrid, Spain. E-mail: tanizeacunha@gmail.com

3 Profs. Drs., Universidade Federal de Pelotas, UFPel, Pelotas, RS, Brasil. E-mail: juli_fernando@yahoo.com.br; chavesfc@, gmail.com; dejalma@msn.com

${ }^{4}$ Discente do Curso de Doutorado do Programa de Pós-Graduação em Agronomia, UFPel, RS, Brasil. E-mail: nardinomn@gmail. com

* Author for correspondence 
assim como avaliar a absorção de água destas sementes. Foram testados quatro genótipos sendo dois de tegumento preto (linhagens IAC e TP) e dois de tegumento amarelo (cultivares BMX Potência RR e CD 202). Inicialmente, as sementes dos quatro genótipos foram multiplicadas, na safra 2012/2013, em casa de vegetação, na Embrapa Clima Temperado - Estação Experimental Terras Baixas. Após a colheita, as sementes ficaram armazenadas, sob condições controladas, durante cinco meses. Depois desse período, junto à UFPel, se determinou a concentração de compostos fenólicos, potencial antioxidante, antocianinas, carotenóides e lignina dos tegumentos. Também se analisou a estrutura interna destes, por meio de cortes anatômicos, sendo a documentação dos resultados realizada pela captura de imagens em microscópio, na Esalq-USP. Por fim, a absorção de água das sementes também foi avaliada, por um período de quarenta e duas horas de embebição. O delineamento foi o inteiramente casualizado, com cinco repetições. Os dados foram submetidos à análise de variância e as médias comparadas pelo teste de Tukey, ao nível de 5\% de probabilidade; com exceção da caracterização estrutural, que constou apenas da análise de imagens. Os dados de embebição foram submetidos à análise de regressão. As concentrações de compostos fenólicos, potencial antioxidante, antocianinas, carotenóides e lignina são maiores nos genótipos de tegumento preto. Esses possuem a camada paliçádica e as células em ampulheta mais espessas em comparação aos genótipos de tegumento amarelo, sendo a camada paliçádica, também, mais lignificada nos tegumentos pretos. A absorção de água das sementes é dependente das condições em que as sementes se formaram, variando entre genótipos, independente da coloração do seu tegumento e da concentração de lignina.

Palavras-chave: Antocianinas, estrutura interna, absorção de água, lignina

\section{Introduction}

Seed coat plays an important protective function in a physiologically mature soybean seeds, contributing to the maintenance of their physiological quality and longevity. However, seed coat may have different levels of resistance to mechanical damage since this feature may be related to its lignin content, while seed longevity and field deterioration level are related to their permeability (ALVAREZ et al., 1997; CAPELETI et al., 2005; FLOR et al., 2004; SOUZA; MARCOS-FILHO, 2001).

Some studies have found that dark-colored seed coats (brown and black) have characteristics of agronomic interest that have not been investigated in soybean seeds with yellow coat. Such contrasting seed coats have greater epidermis thickness, semi-permeability to water, greater resistance to deterioration, and higher concentration of phenolic compounds and lignin, which confer protection against biotic and abiotic factors (MA et al., 2004; MERTZ et al., 2009; SANTOS et al., 2007), and thus it is of interest for research (ANDRADE, 2012).
Nevertheless, despite all the positive characteristics observed in soybeans with black seed coats, these are not used commercially, since these are lineages that have not gone through the process of genetic improvement, nor do they have many of the features that are present in modern cultivars (MERTZ et al., 2009), which are mainly related to plant architecture and its life cycle.

With the narrowing of the soybean genetic base found in modern cultivars, some consequences of this process have reflected on seed quality, more specifically the seed coat fragility (CARRARO; PESKE, 2005). Thus, identifying the characteristics that contribute to seed coat resistance is essential and provides the basis for scientific research. It is also important that plant breeding companies incorporate such features in their cultivars, either by conventional methods or through the use of biotechnological tools, to ensure better quality of seeds.

Given the above, this study aimed to determine the chemical composition and analyze the internal structure of soybean seed coats, as well as to evaluate seed water absorption of four soybean genotypes 
that have contrasting seed coat characteristics, two with yellow coats and two with black coats.

\section{Material and Methods}

Four contrasting soybean genotypes for seed coat characteristics, obtained from the germplasm bank of Coodetec (Cascavel, Paraná, Brazil), were used. Two of them, a conventional CD 202 cultivar with yellow seed coat and a TP lineage with black seed coat, were selected based on the work by Mertz et al. (2009). According to the reports (MERTZ et al., 2009), these lineages have contrasting genotypes for seed coat coloration, semi-permeability, and deterioration level. The other two genotypes, a transgenic BMX Potência RR cultivar and a black seed coat lineage under study by IAC, called IAC, were included in the study to increase the knowledge about seed coat characteristics, associated with two materials of previous studies.

The experiment was conducted in four stages. In the first stage, the seeds were propagated in a greenhouse of Embrapa Clima Temperado - Estação Experimental Terras Baixas (CPAC/ECT) in the city of Capão do Leão, Rio Grande do Sul, Brazil, and new seeds were harvested in the 2012/2013 growing season. Thirty seeds from each genotype were planted in the soil divided into five 8.5-liters plastic buckets. After emergence, the seedlings were thinned, keeping only two seedlings per bucket.

At harvest, the pods were removed and threshed by hand to preserve the maximum integrity of seed coats. Seed moisture content was determined, in order to verify whether they required artificial drying, and then, the seeds were packaged and stored in a cold chamber $\left(15^{\circ} \mathrm{C}\right.$ and $60 \%$ relative humidity) for 5 months.

The second stage was conducted at the Federal University of Pelotas (UFPel), in the laboratory of Secondary Metabolism, Department of Food Science and Technology, and the laboratory of Animal Nutrition, Department of Animal Science, where the chemical composition of seed coat was determined in the four genotypes. For that purpose, coats were carefully separated from the seeds with a scalpel to obtain $10 \mathrm{~g}$ of seed coat for each genotype. We used $2.5 \mathrm{~g}$ of pure seed coat, divided into five replicates of $0.5 \mathrm{~g}$ each, for each of the following assessments:

Total phenolic compound content: It was determined by the method adapted from Swain and Hillis (1959), wherein absorbance was measured on a spectrophotometer at $688 \mathrm{~nm}$ wavelength, and the results were expressed in milligram of gallic acid per gram of sample.

Antioxidant potential: It was determined by the method described by Brand-Williams et al. (1995), which measures the free radical inhibitory capacity of DPPH (2,2-diphenyl-1-picryl-hidrazila). The results were expressed in micromole equivalent to the standard Trolox per gram of sample.

Total anthocyanin content: It was determined by the spectrophotometric method adapted from Lees and Francis (1972), wherein absorbance was measured at $520 \mathrm{~nm}$ wavelength. The anthocyanin content in seed coats of each genotype was expressed in milligram of cyanidin-3-glucoside per gram of sample.

Total carotenoid content in seed coat: It was determined according to the method AOAC 970.64 (2000), and the absorbance was measured at $460 \mathrm{~nm}$ wavelength. The carotenoid content was expressed in microgram of $\beta$-carotene per gram of sample.

Lignin concentration: It was determined from the fiber in seed coats extracted with acid detergent, adopting the lignin method "Klason" according to Van Soest (1967). For this purpose, $5 \mathrm{~g}$ of pure seed coat of each genotype was divided into five replicates of $1 \mathrm{~g}$ each, and the end result was expressed as a percentage of lignin in relation to the initial dry mass of seed coat sample.

The third stage was conducted in the laboratories of Plant Anatomy, Institute of Biology, UFPel and 
the laboratory of Plant Anatomy, Escola Superior de Agriculture Luiz de Queiroz, Universidade de São Paulo (Esalq-USP), where we conducted a comparative analysis of the internal structure of seed coat. To determine the distribution of cell layers in seed coat profile of the four soybean genotypes, two samples of whole seed coat of each genotype were collected and fixed in Karnovsky's solution (KARNOVSKY, 1965; modified using phosphate buffer $\mathrm{pH}$ 7.2), dehydrated in ascending ethanol series, and infiltrated in plastic resin (Leica Historesin $^{\circledR}$, Leica Microsystems Nußloch $\mathrm{GmbH}$, Heidelberg, Germany) according to the manufacturer's instructions.

The samples were cut in a manual rotary microtome (ANCAP) with disposable razor (Feather Safety Razor Co., Ltd., Osaka, Japan). Five micrometers thick sections were stained with $0.05 \%$ toluidine blue (SAKAI, 1973) in phosphate and citrate buffer, $\mathrm{pH} 4.5$, and mounted in a synthetic resin "Entellan" (Merck Millipore, Billerica, MA, USA).

The stained slides were documented with imaging software using a camera Leica DC 300F attached to a microscope Leica DM LB (Leica Microsystems GmbH, Wetzlar, Germany).

The fourth stage of the study was conducted in the Laboratory of Seed and Biotechnology, Department of Plant Science, UFPel. We determined seeds water absorption of the four genotypes, using seeds of standard size which were selected among the seeds that were retained on the sieves with 4.5-5.0 mm round holes. Fifty seeds from each genotype were divided into five $200 \mathrm{~mL}$ plastic cups containing $65 \mathrm{~mL}$ of distilled water. Seed mass was measured on a precision balance $(0.0001 \mathrm{~g})$ with readings conducted every 30 min the first 12 hours; from 12 to 28 hours, the measurements were collected every hour, from 28 to 36 hours every 2 hours, and from 36 to 42 hours, every 3 hours.

The experimental design was completely randomized, with five replications. Data were analyzed by analysis of variance and means were compared by Tukey's test at 5\% probability. Data obtained from the seed-soaking test were evaluated using regression analysis.

\section{Results and Discussion}

The results of the analysis of variance can be observed in Table 1A and 1B. There was a significant difference in the responses of all variables analyzed and significant interaction between genotype and the length of seed imbibition.

Table 1A. Summary of the analysis of variance for components of seed integument in four soybean genotypes.

\begin{tabular}{lllcccc}
\hline \multirow{2}{*}{ S.V. } & \multirow{2}{*}{ DF } & \multicolumn{5}{c}{ Mean square } \\
\cline { 3 - 7 } & & Phenols & Antioxidants & Anthocyanins & Carotenoids & Lignin \\
\hline Genotype & 3 & $10.93^{*}$ & $7042.07^{*}$ & $0.155^{*}$ & $1345.05^{*}$ & $115.84^{*}$ \\
Residue & 16 & 0.002 & 8.23 & 0.002 & 71.39 & 1.94 \\
\hline CV $(\%)$ & & 1.4 & 2.8 & 7.7 & 6.9 & 7.6 \\
\hline
\end{tabular}

S.V. - Sources of variations; DF - Degrees of freedom; *significant at $1 \%$ probability.

Chemical composition of the seed coat in the four genotypes can be seen in Table 2. The concentration of total phenolic compounds was significantly different, with highest values found in genotypes for black seed coat, IAC and TP, but the concentration between them was not significantly different. The significant variation in the antioxidant properties between seed coats 
of the same color. lows: lowest concentration of RR, which was significantly different from those phenolic compounds was found in BMX Potência measured in CD 202.

Table 1B. Summary of the analysis of variance on the interaction between soybean genotypes for seed coat characteristics and imbibition time.

\begin{tabular}{|c|c|c|}
\hline S.V. & DF & Mean square \\
\hline & & Seed imbibition \\
\hline Genotypes & 3 & $3,121.75^{*}$ \\
\hline Imbibition time & 46 & $31,936.86^{*}$ \\
\hline Genotype $\times$ Time & 138 & $677.71 *$ \\
\hline Repetition & 4 & $8,841.64 *$ \\
\hline $\mathrm{R}^{2}$ & & 0.98 \\
\hline CV (\%) & & 10.2 \\
\hline \multicolumn{3}{|l|}{ BMX Potência RR } \\
\hline Time $\times$ Time $\times$ Time & 1 & $55,794.19^{*}$ \\
\hline $\mathrm{R}^{2}$ & & 0.92 \\
\hline \multicolumn{3}{|l|}{ CD 202} \\
\hline Time $\times$ Time $\times$ Time & 1 & $26,667.57^{*}$ \\
\hline $\mathrm{R}^{2}$ & & 0.98 \\
\hline \multicolumn{3}{|l|}{$\mathrm{TP}$} \\
\hline Time $\times$ Time $\times$ Time & 1 & $34,307.21 *$ \\
\hline $\mathrm{R}^{2}$ & & 0.98 \\
\hline \multicolumn{3}{|l|}{ IAC } \\
\hline Time $\times$ Time $\times$ Time & 1 & $36,136.08^{*}$ \\
\hline $\mathrm{R}^{2}$ & & 0.93 \\
\hline
\end{tabular}

Table 2. Concentration of phenolic compounds (Phenols), in mg eq. Galic acid $\mathrm{g}^{-1}$; antioxidant activity, in $\mu$ mol eq. Trolox $\mathrm{g}^{-1}$; total anthocyanins, in $\mathrm{mg}$ eq. Cianidin-3-glucoside $\mathrm{g}^{-1}$; carotenoids, in $\mu \mathrm{g}$ eq. $\beta$ - caroteno $\mathrm{g}^{-1}$; and lignin, in $\%$, in seed coats of four soybean genotypes.

\begin{tabular}{lccccc}
\hline Genotypes & \multicolumn{5}{c}{ Variables } \\
\cline { 2 - 6 } & Phenols & Antioxidants & Anthocyanins & Carotenoids & Lignin \\
\hline IAC & $1.61 \mathrm{a}^{1}$ & $44.58 \mathrm{a}$ & $0.25 \mathrm{a}$ & $33.71 \mathrm{~b}$ & $8.26 \mathrm{a}$ \\
TP & $1.61 \mathrm{a}$ & $44.23 \mathrm{a}$ & $0.18 \mathrm{~b}$ & $42.51 \mathrm{a}$ & $4.99 \mathrm{~b}$ \\
CD202 & $0.16 \mathrm{~b}$ & $6.87 \mathrm{~b}$ & $0.04 \mathrm{~d}$ & $24.29 \mathrm{c}$ & $1.77 \mathrm{~d}$ \\
BMX Potência RR & $0.11 \mathrm{c}$ & $6.88 \mathrm{~b}$ & $0.06 \mathrm{c}$ & $21.79 \mathrm{c}$ & $3.33 \mathrm{c}$ \\
\hline CV $(\%)$ & 1.4 & 2.8 & 7.7 & 6.9 & 7.6 \\
\hline
\end{tabular}

${ }^{1}$ Means followed by different lower case letters in the same row are significantly different according to Tukey's test at $5 \%$ probability.

It is noteworthy that phenol concentrations in the black seed coats were up to 14.5 times higher compared to those in the yellow coats, more specifically in relation to BMX Potência RR. 
Similarly, antioxidant potential of the black seed coat s was significantly higher than that in cultivars with yellow seed coats. There was no significant variation in the antioxidant properties between seed coats of the same color (Table 2).

These results for the total phenolic compounds and antioxidant potential may be related to higher concentration of anthocyanins in soybean genotypes with black seed coat. This is due to the fact that anthocyanins are constituents of phenolic compounds, which are scientifically recognized for its antioxidant properties (RHONE; BASU, 2008).

However, although research has demonstrated the antioxidant properties of soybean with black coat (ZHANG et al., 2011), it is important to note that the concentration of phenolic compounds varies from genotype to genotype and depends on tissue development stage and may also change, depending on the environment (LEPINIEC et al., 2006). The results obtained in this study do not fully agree with Lepiniec et al. (2006), since there was no difference in the content of phenolic compounds as well as in the antioxidant potential between the genotypes with black seed coats, IAC and TP (Table 2).

The standard for anthocyanins indicated greater concentration of these constituents in genotypes with black seed coat. However, difference was observed among genotypes similar in seed color, and the IAC strain showed higher level of anthocyanins compared to TP (Table 2). There was also a difference among the yellow seed coat cultivars; CD 202 cultivar had lower concentration of anthocyanins compared to BMX Potência RR, but it was lower in both than in the two genotypes with black seed coat.

According to Palmer et al. (2004), dark color of the seed coat is regulated by several genes responsible for controlling the accumulation of products such as anthocyanins and proanthocyanidins. Therefore, the results obtained in the present study are in agreement with Palmer et al. (2004), since the highest concentration of anthocyanins was measured in black seed coats.
Flavonoids are synthesized during the formation of seed coat. However, the characteristic dark color, which indicates seeds with the greatest amount of these compounds, such as anthocyanins, occurs toward the end of seed formation. This is due to oxidation, leading to characteristic color (MÖISE et al., 2005). In yellow seed coat genotypes, flavonoids are also present (Table 2), however, in lower concentrations, giving the characteristic lighter color at seed maturity, with a prevalence of carotenoids in relation to anthocyanins.

The high concentration of phenolic compounds can lead to increased seed coat cracking. There are two known types of coat cracking, type I, with irregular cracks and without ramifications and type II, with branched cracks. Both result in separation of the epidermal and hypodermal tissues from the seed coat to expose the underlying parenchymal tissue. Genetic control of these cracks has been well documented and is closely related to pigmented coats, which have higher concentration of anthocyanins in epidermal cells (BENITEZ et al., 2004). However, in the present study, this was not observed in black seed coat genotypes, TP and IAC.

Carotenoids levels differed significantly between black and yellow seed coat genotypes and between the two black seed coat genotypes, whereas they did not differ between the genotypes with yellow seed coats. Black seed coat genotypes had higher levels of carotenoids compared to the yellow seed coat genotypes, with the highest levels found in TP (Table 2).

The concentration of lignin varied significantly between all four genotypes. IAC had the highest concentration, with $8.26 \%$ of lignin present in seed coats, followed by TP, with $4.99 \%$. The lowest concentration of lignin was observed in cultivar CD 202 seed coats with only $1.77 \%$. Intermediate to others, BMX Potência RR, had 3.33\% lignin (Table 2).

These results corroborate the findings by other authors, who observed a greater amount of lignin 
in dark soybean seed coats, contributing to greater resistance of these seed coats to mechanical damage (SOUZA; MARCOS-FILHO, 2001) and protecting the cell wall against the attacks by microorganisms (SANTOS et al., 2007). However, Dantas et al. (2012) did not confirm the protective role of seed coat against the attacks by Aspergillus flavus, although lignin concentration in seed coats of the cultivars they studied did not exceed $0.5 \%$.

According to Alvarez et al. (1997), a good indicator of soybean seed cover strength is the presence of more than 5\% lignin. This amount was found in the black seed coat of IAC genotype, and similar value was observed in TP, the other genotype of the same seed color (Table 2).

According to Gris et al. (2010), genetically modified soybean cultivars for resistance to glyphosate herbicide have been hypothesized to have greater amounts of lignin compared to conventional varieties. This is based on the fact that the modification was made on the shikimic acid cycle, the same that is used by the plant for lignin synthesis. Nevertheless, research in this area is very limited and there are no reports on the difference between conventional cultivars and their respective, essentially derived Roundup Ready versions. Therefore, the Gris et al. (2010) conducted a study with transgenic cultivars and its derivatives, assessing the differences in lignin content in only two cultivars, of which the genetically modified version had greater amount of lignin. However, the levels did not exceed $0.5 \%$, corroborating the observations by Dantas et al. (2012).

The present study also found differences in lignin content in cultivars with yellow seed coats; the transgenic BMX Potência RR cultivar showed a higher level of lignin compared to conventionally cultivated CD 202. It is noteworthy, however, that BMX Potência RR is not essentially derived from CD 202. Therefore, this is an inherent feature of the cultivar, as observed for the genotypes of black seed coats.
Three distinct cell layers were observed on stained cross-sections of the soybean seed coat (Figure 1): the epidermis (palisade), the hypodermis (osteosclereids), and the parenchyma layer (the coat layers are entirely of maternal origin). Moreover, we verified the aleurone layer and the traces of endosperm that is absorbed during seed formation. Our observations of three layers of cells corroborate the observations of scanning electron micrographs of cross sections of soybean seed coats in M-Soy 8400 and M-Soy 8411 (both with yellow seed coat) cultivars by Silva et al. (2008), and by Mertz et al. (2009).

Figure 1 shows that the most external seed coat layer is the palisade layer, formed by elongated thick-walled cells, positioned perpendicularly to the surface of seed coats (MÖISE et al., 2005). It is observed that cells from this layer in cultivars with yellow seed coat, are more uniform, not divided (Figure 1A and $\mathrm{B}$ ) compared to palisade layer in black seed coats (Figure 1C and D), which is partially divided in the central region. This may be related to the fact that black seed coats have greater amount of lignin in the epidermis (ALVAREZ et al., 1997), giving them greater resistance to mechanical impacts and hence, to shear caused by microtome that was used to cut sections of the seed coat.

Furthermore, it was found that the palisade layer in black seed coats is approximately $10 \%$ thicker in relation to the one in yellow seed coats $(44.0 \mu \mathrm{m}$ in seed coat of TP and IAC and $40.0 \mu \mathrm{m}$ in CD 202 and BMX Potência RR) (Figure 1). This is a positive feature, since this region provides mechanical resistance to the seed, and the seed suffers only minor mechanical damage common during harvest, processing, drying, and sowing.

Immediately below the palisade layer are the osteosclereids (hourglass cells) (Figure 1) forming the hypodermis, represented by cells with a varied pattern of intercellular spaces, and also with different thickness between genotypes. The thickness of this layer was similar in both TP and IAC (Figure 1C 
and $\mathrm{D}$ ), and it was thicker than that in genotypes with yellow seed coat. BMX Potência RR had 33\% thicker layer of hourglass cells than CD 202 (Figure
$1 \mathrm{~A}$ and $\mathrm{B})(\mathrm{CD} 202=100 \%$, Potência $=133 \%)$. whereas genotypes of black seed coat had $47 \%$ thicker hypodermis than CD 202 cultivar.

Figure 1.Transversal cross sections of soybean seed coat (Glycine max [L.] Merril) captured by Leica ${ }^{\circledR}$ DC 300F 40x camera attached to microscope Leica ${ }^{\circledR}$ DM LB. Images: A $=$ CD 202; B = BMX Potência RR; C = TP; D = IAC. Black bars $=30 \mu \mathrm{m} ; \mathrm{PL}=$ Palisade layer; $\mathrm{OS}=$ Osteosclereids; $\mathrm{P}=$ Parenchyma, $\mathrm{A}=$ Aleurone layer
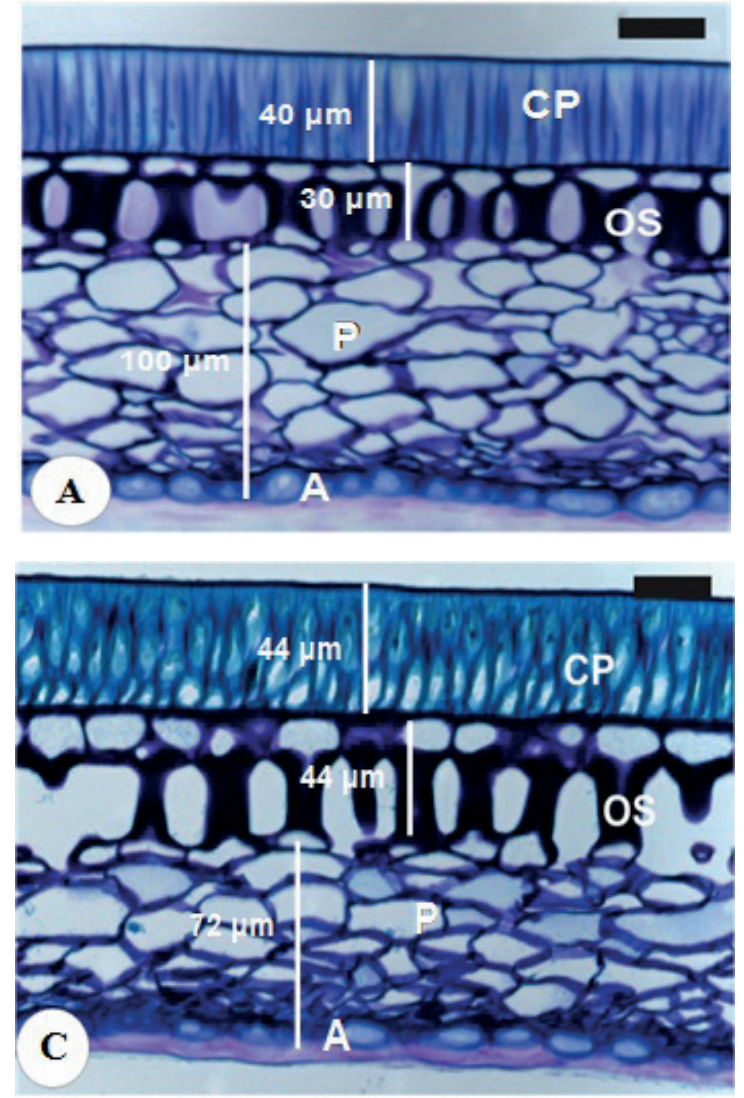

These results are in line with the findings by Mertz et al. (2009) that this layer of cells appeared thicker in the black coat genotype TP opposed to the yellow coat CD 202 genotype.

The hourglass cells originate from the outer layer of the inner seed coat cells (ZENG et al., 2004). Usually, they have more pronounced size than the adjacent cells and are separated by ample intercellular spaces (SOUZA; MARCOS FILHO, 2001).

The presence of many starch grains in the hourglass cells during embryogenesis indicates
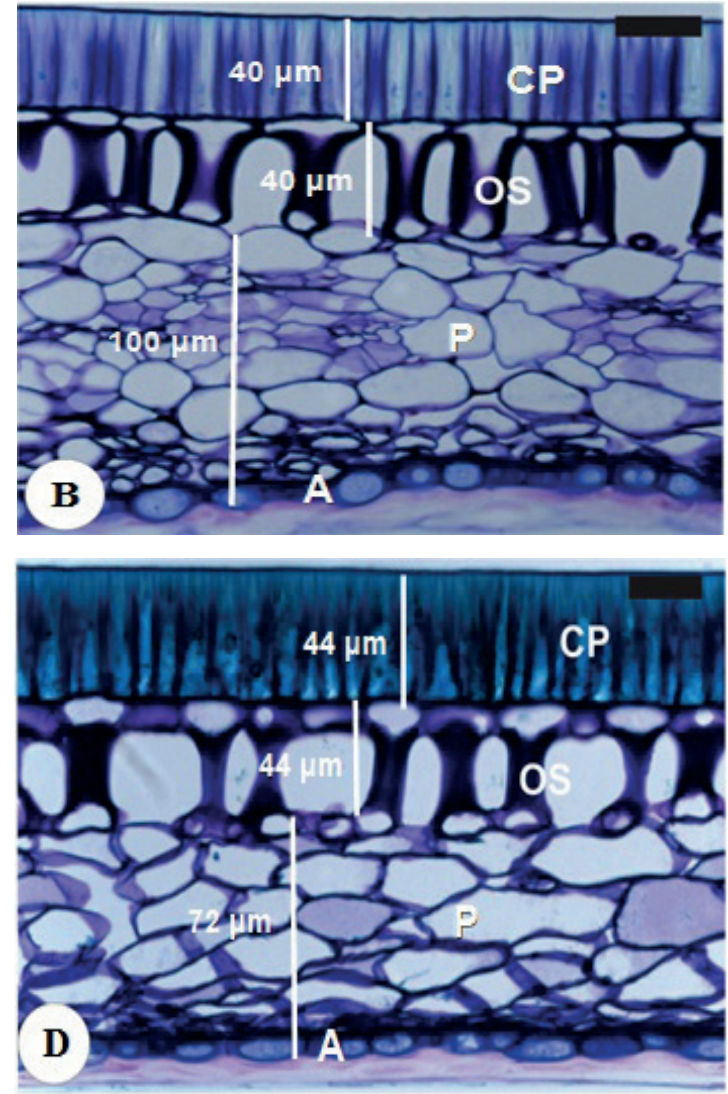

that the seed coat could synthesize nutrients for the developing embryo (WANG, GRUSAK, 2005), similar to the cells of the palisade layer, it also takes part in the mechanical resistance, and serves as a protein reservoir (MÖISE et al., 2005).

To the inside of the seed coat are located the parenchymal cells, comprising of larger cells with more or less cylindrical shape and thin cell wall (Figure 1). In the outermost region of this layer, cells are bigger than the cells located more internally. This may be related to the compression exerted by the growth of cotyledons during seed formation 
(MÖISE et al., 2005). According to Möise et al. (2005), these cells are naturally crushed in the process of seed maturation. These authors also credited to this layer the important role of nutrients transport to embryo during its formation.

The layer of parenchyma cells is $39 \%$ thicker in genotypes with yellow seed coats than in those with black seed coats, and there is no significant difference in thickness between genotypes of the same seed coat color (Figure 1). However, it is noteworthy that this layer, due to its thinner walls, has also a minor role in the resistance of seed coat to the seed.

A study by Mertz et al. (2009) observed similar composition of the three cell layers that comprise the soybean seed coat to that observed in the present study, in particular, the differences in the cell shape and organization in the outer seed coat in relation to the innermost region.

Below the set of parenchymal cells, we observed the aleurone cells (Figure 1), which are apparently higher in genotypes with yellow seed coat (Figure $1 \mathrm{~A}$ and $\mathrm{B}$ ). However, they did not differ substantially from those in IAC genotype (Figure 1D), wherein this layer was somewhat thicker compared to those in other genotypes. The aleurone layer in soybean and other Fabaceae is known for its enzymatic role in mobilizing reserves, such as carbohydrates, during germination (MA et al., 2004).

Observations of the number of cells constituting seed coat revealed that the yellow seed coat genotypes had higher total thickness of seed coat, with $170 \mu \mathrm{m}$ in CD 202 (Figure 1A) and $180 \mu \mathrm{m}$ in BMX Potência RR (Figure 1B), compared to 160 $\mu \mathrm{m}$ in both genotypes with black seed coats, TP and IAC (Figure 1C and D, respectively). These results are important, as they indicate that the black seed coats are not thicker than the yellow seed coats, specifically in this case. However, the layer that confer resistance to seed coats and thus increases seed physiological quality by better preserving their integrity are thicker seed coats with black coloration.

What draws attention in Figure 1 is the clear distinction in coloration of the palisade layer of yellow seed coats (Figure 1A and B) and black seed coats (Figure 1C and D). In the latter, the respective layer of cells is green, whereas, in cells of the yellow seed coats, this layer tends to be blue. This is explained by differential staining of seed coat sections with toluidine blue, a metachromatic dye, which stains the walls rich in pectin purple, cellulose walls stains blue, and lignified walls stains green. These results are in line with the results of lignin quantification conducted in the present study (Table 2).

Given the above, it is evident that concentration of lignin in genotypes with black seed coats is higher than in genotypes with yellow seeds, and that this increased concentration occurs in the epidermis (palisade), thus corroborating Menezes et al. (2009) report of greater amount of lignin in the epidermis as compared to the hypodermis (osteosclereids).

The pattern of seed hydration, step 4, showed a correlation between genotypes and the duration of seed soaking. At the beginning of the soaking process, in the first 4.30 hours, the BMX Potência RR genotypes CD 202 and TP had lower water absorption level compared to IAC genotype. Within 2 hours, and until the end of the first 6 hours, water absorption was higher in IAC and BMX Potência RR than in CD 202 and TP. However, after 7 hours, imbibition in IAC seeds did not differ from that in other genotypes, and neither from that in TP between 8.30 and 9 hours of soaking. Between 9 and 12 hours, there was no difference in water absorption between genotypes. From this moment forward, the reversal was observed in IAC, which decreased water absorption compared to other genotypes. A decrease in imbibition was observed in BMX Potência RR genotype at 24 hours and until the end of the study. At this point of time, imbibition was higher in CD 202 and TP genotypes, but there was no significant difference between the two (Table 3). 
Table 3. Water absorption in four soybean genotypes for each imbibition period.

\begin{tabular}{|c|c|c|c|c|}
\hline \multirow{2}{*}{$\begin{array}{l}\text { Imbibition time } \\
\text { (hours) }\end{array}$} & \multicolumn{4}{|c|}{ Genotypes } \\
\hline & BMX Potência RR & CD 202 & TP & IAC \\
\hline & \multicolumn{4}{|c|}{ Water absorption (\%) } \\
\hline 0.0 & $0.00 \mathrm{~A}$ & $0.00 \mathrm{~A}$ & $0.00 \mathrm{~A}$ & $0.00 \mathrm{~A}$ \\
\hline 0.5 & $7.97 \mathrm{~B}$ & $5.20 \mathrm{~B}$ & $5.72 \mathrm{~B}$ & $23.98 \mathrm{~A}$ \\
\hline 1.0 & $15.82 \mathrm{~B}$ & $9.63 \mathrm{~B}$ & $10.36 \mathrm{~B}$ & $32.65 \mathrm{~A}$ \\
\hline 1.5 & $26.62 \mathrm{~B}$ & $15.34 \mathrm{~B}$ & $16.44 \mathrm{~B}$ & $41.20 \mathrm{~A}$ \\
\hline 2.0 & $37.92 \mathrm{~A}$ & $21.48 \mathrm{~B}$ & $23.41 \mathrm{~B}$ & $48.38 \mathrm{~A}$ \\
\hline 2.5 & $50.96 \mathrm{~A}$ & $28.59 \mathrm{~B}$ & $30.89 \mathrm{~B}$ & $57.83 \mathrm{~A}$ \\
\hline 3.0 & $64.35 \mathrm{~A}$ & $35.96 \mathrm{~B}$ & $37.41 \mathrm{~B}$ & $64.44 \mathrm{~A}$ \\
\hline 3.5 & $77.16 \mathrm{~A}$ & $44.93 \mathrm{~B}$ & $46.08 \mathrm{~B}$ & $72.63 \mathrm{~A}$ \\
\hline 4.0 & $86.43 \mathrm{~A}$ & $51.07 \mathrm{~B}$ & $52.14 \mathrm{~B}$ & $78.15 \mathrm{~A}$ \\
\hline 4.5 & $95.66 \mathrm{~A}$ & $58.36 \mathrm{~B}$ & $59.69 \mathrm{~B}$ & $83.84 \mathrm{~A}$ \\
\hline 5.0 & $101.96 \mathrm{~A}$ & $66.19 \mathrm{~B}$ & $68.60 \mathrm{~B}$ & $90.93 \mathrm{~A}$ \\
\hline 5.5 & $106.97 \mathrm{~A}$ & $73.62 \mathrm{~B}$ & $74.97 \mathrm{~B}$ & $94.82 \mathrm{~A}$ \\
\hline 6.0 & $111.24 \mathrm{~A}$ & $79.67 \mathrm{~B}$ & $81.18 \mathrm{~B}$ & $98.29 \mathrm{~A}$ \\
\hline 6.5 & $114.23 \mathrm{~A}$ & $86.68 \mathrm{~B}$ & $88.90 \mathrm{~B}$ & $103.26 \mathrm{~A}$ \\
\hline 7.0 & $115.82 \mathrm{~A}$ & $90.75 \mathrm{~B}$ & $93.81 \mathrm{~B}$ & $104.16 \mathrm{AB}$ \\
\hline 7.5 & $117.91 \mathrm{~A}$ & $96.54 \mathrm{~B}$ & $100.65 \mathrm{~B}$ & $107.10 \mathrm{AB}$ \\
\hline 8.0 & $119.37 \mathrm{~A}$ & $101.28 \mathrm{~B}$ & $105.72 \mathrm{~B}$ & $108.90 \mathrm{AB}$ \\
\hline 8.5 & $120.86 \mathrm{~A}$ & 104.97 B & $111.29 \mathrm{AB}$ & $111.06 \mathrm{AB}$ \\
\hline 9.0 & $122.02 \mathrm{~A}$ & $108.18 \mathrm{~B}$ & $114.26 \mathrm{AB}$ & $111.77 \mathrm{AB}$ \\
\hline 9.5 & $123.29 \mathrm{~A}$ & $111.56 \mathrm{~A}$ & $117.23 \mathrm{~A}$ & $112.20 \mathrm{~A}$ \\
\hline 10.0 & $123.64 \mathrm{~A}$ & $114.59 \mathrm{~A}$ & $119.56 \mathrm{~A}$ & $112.47 \mathrm{~A}$ \\
\hline 10.5 & $124.55 \mathrm{~A}$ & $118.00 \mathrm{~A}$ & $122.98 \mathrm{~A}$ & $113.67 \mathrm{~A}$ \\
\hline 11.0 & $125.15 \mathrm{~A}$ & $119.48 \mathrm{~A}$ & $125.11 \mathrm{~A}$ & $113.67 \mathrm{~A}$ \\
\hline 11.5 & $125.74 \mathrm{~A}$ & $121.57 \mathrm{~A}$ & $126.66 \mathrm{~A}$ & $114.02 \mathrm{~A}$ \\
\hline 12.0 & $126.12 \mathrm{~A}$ & $122.91 \mathrm{~A}$ & $127.35 \mathrm{~A}$ & $114.11 \mathrm{~A}$ \\
\hline 13.0 & $126.69 \mathrm{AB}$ & $125.00 \mathrm{AB}$ & $129.23 \mathrm{~A}$ & $114.26 \mathrm{~B}$ \\
\hline 14.0 & $127.36 \mathrm{AB}$ & $127.67 \mathrm{AB}$ & $131.32 \mathrm{~A}$ & $114.61 \mathrm{~B}$ \\
\hline 15.0 & $127.77 \mathrm{AB}$ & $128.94 \mathrm{~A}$ & $132.78 \mathrm{~A}$ & $114.93 \mathrm{~B}$ \\
\hline 16.0 & $128.31 \mathrm{AB}$ & $130.74 \mathrm{~A}$ & $134.32 \mathrm{~A}$ & $115.00 \mathrm{~B}$ \\
\hline 17.0 & $128.67 \mathrm{~A}$ & $132.10 \mathrm{~A}$ & $135.38 \mathrm{~A}$ & $115.25 \mathrm{~B}$ \\
\hline 18.0 & $129.09 \mathrm{~A}$ & $133.45 \mathrm{~A}$ & $136.28 \mathrm{~A}$ & $115.63 \mathrm{~B}$ \\
\hline 19.0 & $129.56 \mathrm{~A}$ & $135.29 \mathrm{~A}$ & $138.34 \mathrm{~A}$ & $115.98 \mathrm{~B}$ \\
\hline 20.0 & $129.98 \mathrm{~A}$ & $136.64 \mathrm{~A}$ & $140.12 \mathrm{~A}$ & $116.38 \mathrm{~B}$ \\
\hline 21.0 & $130.37 \mathrm{~A}$ & $137.67 \mathrm{~A}$ & $140.88 \mathrm{~A}$ & $116.62 \mathrm{~B}$ \\
\hline 22.0 & $131.99 \mathrm{~A}$ & $139.20 \mathrm{~A}$ & $142.63 \mathrm{~A}$ & $117.28 \mathrm{~B}$ \\
\hline 23.0 & $131.61 \mathrm{~A}$ & $141.29 \mathrm{~A}$ & $143.77 \mathrm{~A}$ & $117.94 \mathrm{~B}$ \\
\hline 24.0 & $132.00 \mathrm{~B}$ & $144.41 \mathrm{~A}$ & $145.92 \mathrm{~A}$ & $117.98 \mathrm{~B}$ \\
\hline 25.0 & $132.00 \mathrm{~B}$ & $145.50 \mathrm{~A}$ & $145.92 \mathrm{~A}$ & $117.98 \mathrm{~B}$ \\
\hline 26.0 & $132.00 \mathrm{~B}$ & $148.10 \mathrm{~A}$ & $147.16 \mathrm{~A}$ & $118.82 \mathrm{~B}$ \\
\hline 27.0 & $132.00 \mathrm{~B}$ & $148.10 \mathrm{~A}$ & $147.16 \mathrm{~A}$ & $118.82 \mathrm{~B}$ \\
\hline 28.0 & $133.20 \mathrm{~B}$ & $152.87 \mathrm{~A}$ & $149.69 \mathrm{~A}$ & $120.24 \mathrm{~B}$ \\
\hline 30.0 & $133.80 \mathrm{~B}$ & $155.68 \mathrm{~A}$ & $151.68 \mathrm{~A}$ & $121.60 \mathrm{~B}$ \\
\hline 32.0 & $134.08 \mathrm{~B}$ & $157.18 \mathrm{~A}$ & $153.30 \mathrm{~A}$ & $122.82 \mathrm{~B}$ \\
\hline 34.0 & $134.49 \mathrm{~B}$ & $158.41 \mathrm{~A}$ & $155.71 \mathrm{~A}$ & $126.18 \mathrm{~B}$ \\
\hline 36.0 & $135.82 \mathrm{~B}$ & $158.88 \mathrm{~A}$ & $157.40 \mathrm{~A}$ & $126.48 \mathrm{~B}$ \\
\hline 39.0 & $136.82 \mathrm{~B}$ & $159.28 \mathrm{~A}$ & $158.09 \mathrm{~A}$ & $128.02 \mathrm{~B}$ \\
\hline 42.0 & $137.94 \mathrm{~B}$ & $159.56 \mathrm{~A}$ & $158.63 \mathrm{~A}$ & $128.34 \mathrm{~B}$ \\
\hline CV (\%) & 10.2 & & & \\
\hline
\end{tabular}

*means followed by different letters in the same row are significantly differently Tukey test at $5 \%$ probability. 
By analyzing seed soaking of each genotype individually for the entire study period, we observed similar behavior in the first 9 hours of seed hydration in CD 202 and TP genotypes, which imbibed slower than BMX Potência RR and IAC. Initially, the latter had higher imbibition rate than the other genotype in the first hour, and later it was exceeded by BMX Potência RR (Figure 2).

Figure 2. Water absorption by seeds of four soybean genotypes according to imbibition time.

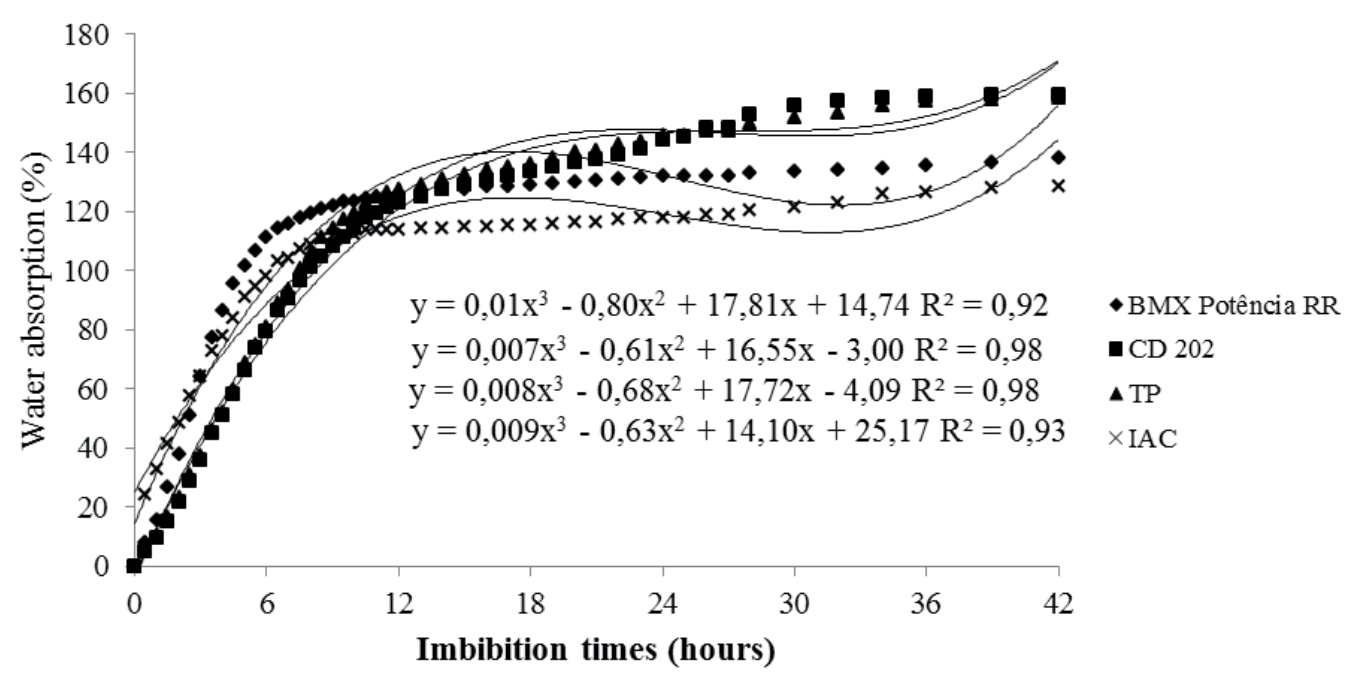

The first genotype that stabilized the imbibition was IAC, after approximately 10 hours of hydration, followed by BMX Potência RR. For CD 202 and TP genotypes, imbibition increased very gradually, starting from 13 hours of water absorption. All genotypes, while reducing water absorption at the end of the study period, showed a slight increase in imbibition at about 33 hours (Figure 2).

Radicle in BMX Potência RR and CD 202 emerged after approximately 30 hours of imbibition. This result does not coincide with those observed by Carvalho et al. (2012). According to these authors, the radicle protrusion in cultivars with yellow seed coat CD 206 RR and CD 206 conventional occurred after 38 to 39 hours of soaking, respectively, which time is well above the time observed in the present study.

In TP genotype, the radicle was evident after approximately 28 hours of seed soaking, and in IAC at only 23 hours, protrusion was faster than in seeds of other genotypes. These results are important since faster seed germination and seedling emergence under field conditions results in reduced exposure of seeds to likely attacks by pathogenic microorganisms. This semi-permeability credited to black coats genotypes is related to higher concentration of lignin. However, based on the amount of lignin in black seed coats, it is especially reinforced in IAC (Table 2). The hydration pattern (Table 3) that was reported by other authors (GRIS et al., 2010) was not confirmed in the present study, as cultivar CD 202, which had the lowest lignin concentration in seed coats among the evaluated genotypes, imbibed more slowly along with TP and in the first hours of soaking.

\section{Conclusions}

The concentration of phenolic compounds, antioxidant potential, anthocyanins, carotenoids, and lignin are higher in genotypes with black seed coats.

The palisade layer and hourglass cells in IAC and TP lineages with black seed coat are thicker than 
in cultivars with yellow seed coat, BMX Potência $\mathrm{RR}$ and CD 202. The palisade layer is also more lignified in tested strains.

The water gain in seeds is probably dependent upon conditions encountered by each seed during its formation, varying between genotypes regardless of seed coat color and its lignin content.

\section{Acknowledgements}

We are thankful to the laboratories of Plant Anatomy of UFPel and Esalq-USP and to the laboratory of Animal Nutrition and Secondary Metabolism of UFPel for providing space and assistance for analysis.

This research was supported by scholarship and other funding provided by $\mathrm{CNPq}$, CAPES, and FAPERGS.

\section{References}

ALVAREZ, P. J. C.; KRZYZANOWSKI, F. C.; MANDARINO, J. M.; FRANÇA-NETO, J. B. Relationship between soybean seed coat lignin content and resistance to mechanical damage. Seed Science \& Technology, Cambridge, v. 25, n. 2, p. 209-21, 1997.

ANDRADE, E. R. de. Caracterização e comparação da linhagem de soja UNB 1125 de tegumento preto com genótipos comerciais. 2012. Monografia (Trabalho de Conclusão de Curso de Agronomia) - Faculdade de Agronomia e Medicina Veterinária, Universidade Nacional de Brasília, Brasília.

ASSOCIATION OF OFFICIAL ANALYTICAL CHEMISTS - AOAC. Official method 900.02, 920.36 C, 970.64, 979.09. 17. ed. Gaithersburg, MD: AOAC International, 2000.

BENITEZ, E. R.; FUNATSUKI, H.; KANEKO, Y.; MATSUZAWA, Y.; BANG, S. W.; TAKAHASHI, R. Soybean maturity gene effects on seed coat pigmentation and cracking in response to low temperatures. Crop Science, Madison, v. 44, n. 6, p. 2038-2042, 2004.

BRAND-WILLIAMS, W.; CUVELIER, M. E.; BERSET, C. Use of a free radical method to evaluate antioxidant activity. Lebensmittel-Wissenschaft und Technologie, London, v. 28, n. 1, p. 25-30, 1995.
CAPELETI, I.; FERRARESE, M. L. L.; KRZYZANOWSKI, F. C.; FERRARESE-FILHO, O. A new procedure for the quantification of lignin in soybean (Glycine max (L.) Merrill) seed coat and their relationship with the resistance to mechanical damage. Seed Science \&Technology, Cambridge, v. 33, n. 2, p. 511-515, 2005.

CARRARO, I. M.; PESKE, S. T. Uso de sementes de soja no estado do Paraná. Revista Brasileira de Sementes, Londrina, v. 27, n. 2, p. 75-80, 2005.

CARVALHO, T. C. de; GRZYBOWSKI, C. R. de S.; OHLSON, O. de C.; PANOBIANCO, M. Comparação da qualidade fisiológica de sementes de soja convencional e de sua derivada transgênica. Revista Brasileira de Sementes, Londrina, v. 34, n. 1, p. 164-170, 2012.

DANTAS, I. B.; OLIVEIRA, J. A. de; SANTOS, H. O. dos; VON PINHO, E. V. R.; ROSA, S. D. V. F. da. Influence of lignin content in soybean seed coat on the incidence of the storage fungus Aspergillus flavus. Revista Brasileira de Sementes, Londrina, v. 34, n. 4, p. 541-548, 2012.

FLOR, E. P. O.; CICERO, S. M.; FRANÇA NETO, J. de B.; KRZYZANOWSKI, F. C. Avaliação de danos mecânicos em sementes de soja por meio da análise de imagens. Revista Brasileira de Sementes, Londrina, v. 26, n. 1, p. 68-76, 2004.

GRIS, C. F.; VON PINHO, E. V. de R.; ANDRADE, T.; BALDONI, A.; CARVALHO, M. L. de M. Qualidade fisiológica e teor de lignina no tegumento de sementes de soja convencional e transgênica RR submetidas a diferentes épocas de colheita. Ciência e Agrotecnologia, Lavras, v. 34, n. 2, p. 374-381, 2010.

KARNOVSKY, M. J. A formaldehyde-glutaraldehyde fixative of high osmolality for use in electron microscopy. Journal of Cell Biology, New York, v. 27, n. 15, p. 137138, 1965.

LEES, D. H.; FRANCIS, F. J. Standardization of pigment analysis in Cranberries. Hortscience, Alexandria, v.7, n. 1, p.83-84, 1972.

LEPINIEC, L.; DEBEAUJON, I.; ROUTABOUL, J.; BAUDRY, A.; POURCEL, L.; NESI, N.; CABOCHE, M. Genetics and biochemistry of seed flavonoids. Annual Review of Plant Biology, California, v. 57, n. 1, p. 405430, 2006.

MA, E.; CHOLEWA, E.; MOHAMED, T.; PETERSON, C. A.; GIJKEN, M. Cracks in the palisade cuticle of soybean seed coats correlate with their permeability to water. Annals of Botany, Exeter, v. 94, n. 2, p. 213-228, 2004. 
MENEZES, M. de; VON PINHO, E. V. de R.; ROVERI JOSÉ, S. C. B.; BALDONI, A.; MENDES, F. F. Aspectos químicos e estruturais da qualidade fisiológica de sementes de soja. Pesquisa Agropecuária Brasileira, Brasília, v. 44, n. 12, p. 1716-1723, 2009.

MERTZ, L. M.; HENNING, F. A.; CRUZ, H. L. da; MENEGHELlO, G. E.; FERRARI, C. dos S.; ZIMMER, P. D. Diferenças estruturais entre tegumentos de sementes de soja com permeabilidade contrastante. Revista Brasileira de Sementes, Londrina, v. 31, n. 1, p. 23-29, 2009.

MOÏSE, J. A.; HAN, S.; GUDYNAITE-SAVITCH, L.; JOHNSON, D. A.; MIKI, B. L. A. Seed coats: structure, development, composition, and biotechnology. In Vitro Cellular \& Developmental Biology - Plant, Columbia, v. 41, n. 5, p. 620-644, 2005.

PALMER, R. G.; PFEIFFER, T. W.; BUSS, G. R.; KILEN, T. C. Quantitative genetics. In: BOERMA, H. R.; SPECHT, J. E. (Ed.). $3^{\text {th }}$ ed. Soybeans: improvement, production, and uses. Madison: American Society of Agronomy, 2004. p. 137-233.

RHONE, M.; BASU, A. Phytochemicals and age-related eye diseases. Nutritions Reviews, Washington, DC, v. 66, n. 8, p. 465-472, 2008.

SAKAI, W. S. Simple method for differential staining of paraffin embedded plant material using toluidine blue $\mathrm{O}$. Biotechnic \& Histochemistry, Baltimore, v. 48, n. 5, p. 247-249, 1973.

SANTOS, E. L. dos; PÓLA, J. N.; BARROS, A. S. do R.; PRETE, C. E. C. Qualidade fisiológica e composição química das sementes de soja com variação na cor do tegumento. Revista Brasileira de Sementes, Londrina, v. 29, n. 1, p. 20-26, 2007.
SILVA, M. A. D. da; VIEIRA, R. D.; SANTOS, J. M. dos. Influência do envelhecimento acelerado na anatomia da testa de sementes de soja, cv. Monsoy 8400. Revista Brasileira de Sementes, Londrina, v. 30, n. 2, p. 91-99, 2008.

SOUZA, F. H. D. de; MARCOS-FILHO, J. The seed coat as a modulator of seed - environment relationships in Fabaceae. Brazilian Journal of Botany, São Paulo, v. 24, n. 4, p. 365-375, 2001.

SWAIN, T.; HILLIS, W. E. The phenolic constituents of Prunus domestica L. The quantitative analysis of phenolic constituents. Journal of the Science of Food and Agriculture, London, v. 10, n. 1, p. 63-68, 1959.

VAN SOEST, P. J. Development of a comprehensive system of feed analysis and its applications to forage. Journal of Animal Science, Champaign, v. 26, n. 1, p. 119-128, 1967.

WANG, H. L.; GRUSAK, M. A. Structure and development of Medicago truncatula pod wall and seed coat. Annals of Botany, United Kingdon, v. 95, n. 5, p. 737-747, 2005

ZENG, C. L.; WANG, J. B.; LIU, A. L.; WU, X. M. Seed coat microsculpturing changes during seed development in diploid and amphidiploid Brassica species. Annals of Botany, Exeter, v. 93, n. 5, p. 555-566, 2004.

ZHANG, R. F.; ZHANG, F. X.; ZHANG, M. W.; WEI, Z. C.; YANG, C. Y.; ZHANG, Y.; TANG, X. J.; DENG, Y. Y.; CHI, J. W. Phenolic composition and antioxidant activity in seed coats of 60 chinese black soybean (Glycine max L. Merr.) varieties. Journal of Agricultural and Food Chemistry, Easton, v. 59, n. 11, p. 5935-5944, 2011. 
